\section{Qstetik}

Jurnal Bahasa Indonesia
Institut Agama Islam Negeri (IAIN) Curup, Indonesia

ISSN 2622-1810 (p); 2622-1829 (e)

volume 4, number 1, 2021 | page: 87-114

DOI: http://doi.org/10.29240/estetik.v4i1.2483

\title{
Unsur Pembangun dalam Sastra Anak Novel Mata di Tanah Melus Karya Okky Madasari: Kajian Strukturalisme
}

\author{
Nur Cahyati, Heny Friantary, Ixsir Eliya \\ Institut Agama Islam Negeri (IAIN) Bengkulu, Indonesia \\ nurcahyati1711@gmail.com, henyfriantary30@gmail.com, \\ eliyaixsir@gmail.com
}

\begin{abstract}
Children's literature produced in Indonesia it self is not too much and studies are rarely carried out. Therefore, it is important to have an assessment of children's literature, especially novels. The research objective was to describe the building blocks in Okky Madasari's Mata di Tanah Melus novel. The approach used in this research is a structuralism approach. The research method used content analysis method. The data source is the novel Mata di Tanah Melus by Okky Madasari. The research time was carried out for one month. Data collection techniques using library techniques. The data collection instrument was the novel Mata di Tanah Melus by Okky Madasari. The data validity technique uses credibility testing techniques, namely increasing persistence and using reference materials. Data analysis in this study used Miles and Huberman's analysis model, namely data collection, data reduction, data presentation, and conclusions. The results showed that the building blocks found in the novel Mata di Tanah Melus, namely the facts of the story in the form of a forward plot. The main character is Matara, the supporting character consists of 18 people, the white character consists of 5 people, and the black character is the Hunters. The setting consists of 17 places. The time setting occurs in the morning, noon, and night. The socio-cultural background raises the culture of the Melus Tribe. The theme raised in the novel Mata di Tanah Melus is the theme of humanity. The means of the story are titles and points of view. The title of the novel contains two meanings and experiences semantic distortion. The point of view used is the main actor's first person point of view.
\end{abstract}

Keywords: Children's Literature, Instristic Elements, Novels, Structuralism Studies

Abstrak. Sastra Anak yang dihasilkan di Indonesia sendiri tidak terlalu banyak dan pengkajiannya pun jarang dilakukan. Oleh karena itu, penting adanya pengkajian terhadap sastra anak khususnya novel. Tujuan penelitian untuk mendeskripsikan unsur pembangun dalam novel Mata di Tanah Melus karya Okky Madasari. Pendekatan yang digunakan dalam penelitian ini adalah pendekatan strukturalisme. Metode penelitian menggunakan metode content analysis. Sumber data berupa novel Mata di Tanah Melus karya Okky Madasari. 
Waktu penelitian dilakukan selama satu bulan. Teknik pengumpulan data menggunakan teknik pustaka. Instrumen pengumpulan data berupa novel Mata di Tanah Melus karya Okky Madasari. Teknik keabsahan data menggunakan teknik pengujian kepercayaan (credibility), yaitu meningkatkan ketekunan dan menggunakan bahan referensi. Analisis data pada penelitian ini menggunakan model analisis Miles dan Huberman, yaitu pengumpulan data, reduksi data, penyajian data, dan kesimpulan. Hasil penelitian menunjukan bahwa unsur pembangun yang ditemukan pada novel Mata di Tanah Melus, yaitu fakta cerita berupa alur maju. Tokoh utama adalah Matara, tokoh pembantu terdiri dari 18 orang, tokoh putih berjumlah 5 orang, dan tokoh hitam ialah Para Pemburu. Latar tempat terdiri dari 17 tempat. Latar waktu terjadi pada pagi, siang, dan malam. Latar sosial-budaya mengangkat budaya Suku Melus. Tema yang diangkat dalam novel Mata di Tanah Melus berupa tema kemanusiaan. Sarana cerita berupa judul dan sudut pandang. Judul novel yang mengandung dua arti dan mengalami penyimpangan semantis. Sudut pandang yang digunakan adalah sudut pandang orang pertama pelaku utama.

Kata Kunci: Sastra Anak, Unsur Instristik, Novel, Kajian Strukturalisme

\section{Pendahuluan}

Seiring berkembangnya arus globalisasi membuat terkikisnya pendidikan karakter pada anak. Dampak arus globalisasi terlihat dari munculnya fenomena menarik yang menimpa generasi muda, yaitu saat ini generasi anak Indonesia kurang menyukai bacaan sastra anaka seperti, dongeng, pusi, lagu dolanana, cerpen, dan novel anak. Sastra anak yang dihasilkan di Indonesia sendiri tidak terlalu banyak dan pengkajiannyapun dalam dunia sastra sedikit terabaikan. Padahal jika kita lihat dalam kehidupan sehari-hari peran pemilihan sastra anak oleh orang tua sangat dibutuhkan sebagai perantara penyampaian nilai moral dan pendidikan karakter bagi anak.

Menurut Nurgiyantoro (2016: 8) Sastra anak adalah sastra yang secara emosional psikologis dapat ditanggapi dan dipahami oleh anak yang berangkat dari fakta konkret yang dapat diimajinasikan. Dalam sebuah sastra terdapat sebuah genre sastra anak. Lukens mengatakan bahwa sastra anak merupakan sebuah karya yang menawarkan dua hal utama, yaitu kesenangan dan pemahaman. Sastra hadir memberikan kehidupan yang menyenangkan dan menghibur bagi anak karena menampilkan cerita menarik, mengajak pembaca untuk memajukan fantasi, membawa pembaca ke suatu alur kehidupan yang menarik hati pembaca untuk ingin tahu dan terikat karenanya, dan semuanya dikemas 
dengan menarik sehingga pembaca mendapatkan kesenangan dan hiburan.

Sastra Anak yang dihasilkan di Indonesia sendiri tidak terlalu banyak dan pengkajiannya pun jarang dilakukan. Oleh karena itu, penting adanya pengkajian terhadap sastra anak khususnya novel. Kajian strukturalisme termasuk pendekatan yang berorientasi pada pendekatan objektif. Pengkajian sastra anak dengan kajian strukturalisme dapat membedah sebuah karya sastra secara struktur, mampu mengupas sebuah karya sastra secara mendalam. Strukturalisme dapat dikatakan sebagai sebuah kajian yang sudah ;ama. Akan tetapi, keberadaannya masih tetap digunakan dan sering dijadikan sebagai pendekatan dalam mengakaji karya sastra seperti novel dan cerpen.

Sastra anak telah memiliki pengaruh sosial dan pendidikan yang besar. Sejak pertengahan abad ke-18 sastra anak telah dikenal sebagai jenis teks yang berbeda. Sastra anak telah ada pada abad ke-18. Namun, pada abad ke-20 sekarang pemerhati sastra anak sangat sedikit. Beberapa pemerhati sastra anak, diantaranya adalah Heru Kurniawan, Bambang Trimasyah, Burhan Nugiantoro, Sugihastuti, Riris K. Toha Sarumpeat, dan Murti Bunanta. Hal ini diperkuat dengan buku-buku yang telah diterbitakan oleh mereka. Salah satunya buku Sastra Anak karya Burhan Nurgiantoro.

Sastra anak di Indonesia mulai berkembang pada tahun 1945. Anak-anak mulai mengenal cerita-cerita yang mengandung unsur didaktis. Cerita anak yang berkembang seperti dongeng, buku cerita, dan buku-buku terjemahan dari luar negeri. Pada tahun 1945 buku bacaan anak dianggap kurang memadai. Buku bacaan anak masih sangat langka. Kalaupun ada isi yang terdapat dalam buku bacaan cenderung mengedepankan pendidikan dan pengajaran terutama pengajaran moral. Hal ini terbukti dengan adanya buku-buku adaptasi dari luar negeri yang diterjemahkan oleh Indonesia. Cerita anak yang berkembang pada abad ke-20 khususnya di Indonesia cukup tertinggal diantara negara-negara maju yang lain. Cerita yang berkembang masih banyak mengangkat cerita-cerita legenda daripada cerita fantasi. Hal ini menunjukkan bahwa sastra anak di Indonesia kurang diperhatikan dan kurang diminati. 


\section{Pendekatan Strukturalisme}

Sastra anak adalah karya sastra yang secara khusus dapat dipahami oleh anak-anak dan berisi tentang dunia yang akrab dengan anak-anak, yaitu anak yang berusia antara 3-12 tahun (Puryanto, 2008: 2). Pendekatan strukturlisme mengkaji karya sastra secara otonom dan melepaskan diri dari berbagai karya sastra. Keotonomian karya sastra ini berangkat dari konsep strukturalisme, yaitu cara berpikir yang menganggap bahwa dunia lebih terbentuk dari hubungan-hubungan antar unsur yang tiap-tiap unsurnya tidak mempunyai makna dengan sendirinya, dan maknanya ditentukan oleh hubungannya dengan unsurunsur lain yang terlibat dalam sebuah situasi. (Heru Kurniawan, 2013:67)

Kajian ini berorientasi pada pendekatan objektif yang dapat membedah sebuah karya sastra secara struktur, mampu mengupas sebuah karya sastra secara mendalam, dan menganalisis secara cermat dan seteliti mungkin mengenai unsur-unsur pembangun dalam cerita.

\section{Unsur Pembangun Novel}

Dalam kajian strukturalisme, unsur-unsur pembangun karya sastra (prosa fiksi), meliputi fakta cerita, tema, dan sarana cerita (Robert Stanton, )

\section{Fakta Cerita}

Fakta cerita sebagai salah satu informasi yang berupa fakta yang terdapat di dalam suatu karya yang meliputi satu informasi yang berupa fakta yang terdapat dalam suatu karya yang meliputi alur, karakter, dan latar. Struktur faktual adalah cerita yang disorot dari sudut pandang (Pujiharto, 2012: 27).

\section{Tokoh}

Dalam cerita fiksi sastra anak, tokoh pada sebuah cerita tidak harus berwujud manusia, melainkan dapat berupa binatang atau suatu objek yang lain yang biasanya merupakan bentuk personifikasi dari manusia (Burhanudin, 2016: 223).

\section{Alur}


Alur cerita dalam sebuah fiksi menyajikan peristiwa-peristiwa atau kejadian-kejadian kepada pembaca tidak hanya dalam sifat kewaktuan atau temporalnya, tetapi juga dalam hubungan-hubungan yang sudah diperhitungkan (Sayuti, A. Suminto, 2000: 30).

\section{Latar}

Latar dapat dipahami sebagai landasan berlangsungnya berbagai peristiwa dan kisah yang diceritakan dalam cerita fiksi. Latar menunjuk pada tempat, yaitu lokasi dimana sebuah cerita terjadi dan lingkungan sosial-budaya, keadaan kehidupan tempat tokoh dan peristiwa terjadi (Burhan Nurgiantoro, 2016: 228)

\section{Tema}

Tema merupakan dasar pengembangan sebuah cerita. Lukkens mendefinisikan bahwa sastra anak sebagai sebuah kebenaran yang sugnifikan yang diekspresikan ke dalam elemen-elemen yang layak dan bahasa yang mengesankan, kebenaran yang esensial itu adalah tema. (Burhan Nurgiantoro, 2016: 260).

\section{Sarana Cerita}

Staton mendefinisikan sarana cerita sebagai metode (pengarang) dalam memilih dan menyusun detail cerita agar tercapai pola-pola yang bermakna (Heru Kurniawan, 2013:76). Dalam buku Stanton (Sugihastuti dan Rossi Abi Al Irsyad, 2007: 51) menjelaskan bahwa sarana-sarana cerita yang paling signifikant, yaitu karakter, konflik, dan tema.

\section{Judul}

Judul merupakan elemen fiksi yang pertama dibaca oleh pembaca. Oleh karena itu, judul mudah dikenali oleh pembaca. Biasanya judul dari cerita adalah cerminan dari isi cerita secara keseluruhan (Heru Kurniawan, 2013:78).

\section{Sudut Pandang}

Abraham mengemukaan bahwa sudut pandang merupakan cara atau pandangan yang dipergunakan pengarang sebagai sarana menampilkan tokoh, tindakan, latar, dan berbagai peristiwa yang 
membentuk cerita dalam sebuah teks fiksi pada pembaca (Burhan Nurgiantoro, 2016: 269).

Adapun penelitian terdahulu, yaitu berjudul“Analisis Buku Bacaan Anak "Belajar Sambil Berternak Ayam" Berdasarkan Pendekatan Stuktural" oleh Mila Roysa (2017). hasil penelitian menunjukan bahwa teks cerita yang berjudul "Belajar Sambil Berternak Ayam" sesuai untuk pengoptimalan kognitif anak. Penelitian ini menunjukan dengan menggunakan pendekatan struktural, peneliti mampu mendeskripsikan unsur pembangun cerita seperti alur cerita tentang persahabatan yang kental dan ada pengkhianatan, petualangan, pencariaan dan penemuan sesuatu persaingan dalam mencapai sesuatu. Persamaan penelitian ini dengan penelitian yang akan dilakukan oleh penulis yaitu terletak dari jenis kajian yang digunakan dan genre sastra yang diteliti. Kajian yang diteliti sama-sama kajian strukturalisme bergenre sastra anak. Adapun perbedaan dari penelitian ini dengan penelitian yang akan dilakukan oleh penulis, yaitu terletak pada masalah yang dibahas. Penelitian ini membahas mengenai kajian strukturalisme dengan teknik deskriptif kualitatif, sedangkan penelitian yang akan dilakukan oleh penulis membahas tentang strukturalisme dengan metode Content Analysis.

Penelitian Pandu Dian Samaran, Amrizal, dan Bustanudin Lubis (2018) dengan judul "Analisis Struktural Novel O Karya Eka Kurniawan". Hasil penelitian ini berupa unsur-unsur struktur pembangun novel $O$ karya Eka Kurniawan. Tema yang terdapat dalam novel ini adalah kehidupan. Alur yang digunakan dalam novel $O$ adalah alur regresif. Tokoh utamanya adalah 0, Entang Kosasih. Sobar, Joni Simbolon, Betalumur, Kirik, Toni Bagong, Dara. Latar tempat dalam novel $O$ adalah Rawa Kalong, bangku, gang-gang kecil permukiman. Latar waktu dalam novel $O$ adalah sore, pagi hari, subuh. Latar sosial dalam novel $O$ adalah latar sosial kelas rendah. Sudut pandang yang digunakan dalam novel $O$ adalah sudut pandang diaan maha tahu. Amanat dalam novel $O$ adalah kehidupan yang terus berputar seperti lingkaran atau seperti huruf 0 . Persamaan penelitian ini dengan penelitian ini, yaitu teori yang digunakan dalam menganalis data sama-sama menggunakan teori strukturalisme. 
Penelitian Husnul Septiana dan Siti Isnaniah. (2020) dengan judul "Kajian Struktural dan Nilai-Nilai Pendidikan dalam Novel Hayya karya Helvtyana Rosa dan Benny Arnas". Hasil Penelitian menunjukan bahwa unsur-unsur yang membentuk struktural novel Hayya meliputi: tema, tokoh, penokohan, latar, alur, dan sudut pandang. Adapun nilai pendidikan yang terdapat pada novel Hayya, yaitu nilai pendidikan religius, nilai pendidikan sosial, nilai pendidikan budaya, dan nilai pendidikan karakter. Persamaan antara penelitian ini dengan penelitian yang akan dilakukan oleh penulis, yaitu sama-sama menggunakan teknik teknik analilis isi dokumen analilis strukturalisme berupa unsur intrinsik. Perbedaan antara penelitian ini dengan penelitian yang akan dilakukan oleh penulis, yaitu terletak pada permasalahan dan objek kajiannya. Dalam hal ini penulis akan meneliti nilai-nilai pendidikan karakter dalam novel Mata di Tanah Melus karya Okky Madasari, sedangkan pada penelitian ini peneliti mengkaji novel Hayya untuk menemukan nilai-nilai pendidikan.

\section{Metode Penelitian}

Penelitian ini menggunakan pendekatan strukturalisme. Menurut Hawks (dalam Jabrohim, 2012: 69) strukturalisme adalah cara berpikir tentang dunia yang dikaitkan dengan persepsi dan deskripsi struktur; atau sebuah struktur yang unsur- unsurnya atau bagian-bagiannya saling berhubungan antara bagian yang satu dengan bagian yang lain.

Metode yang digunakan dalam penelitian ini adalah Metode content analysis, yaitu metode yang ditujukan untuk mengumpulkan dan menganalisis dokumen. Setelah peneliti mengumpulkan sejumlah data yang berkaitan dengan tema dan pembahasan dalam penelitian ini, maka peneliti segera memulai pesan analisa data-data tersebut. Dalam proses tersebut hal pertama yang harus dilakukan adalah mengklasifikasi data dan membaca secara berulang-ulang mengenai isi novel.

Sumber data yang dipergunakan dalam penelitian ini adalah novel berjudul Mata di Tanah Melus karya Okky Madasari, cetakan pertama tahun 2018 dan diterbitkan oleh PT Gramedia Pustaka Utama Jakarta pada tahun 2018 di Jakarta. Dengan tebal novel 187 halaman, 
sedangkan data penelitian berupa kutipan-kutipan kalimat dan paragraf dalam novel Mata di Tanah Melus karya Okky Madasari.

Teknik pengumpulan data yang digunakan dalam penelitian ini adalah teknik baca dan catat. Teknik baca di-gunakan untuk memperoleh data-data yang terdapat dalam novel Mata di Tanah Melus karya Okky Madasari dan teknik mencatat digunakan untuk mencatat kalimatkalimat atau kutipan dalam novel Mata di Tanah Melus.

\section{Hasil dan Pembahasan}

Data yang didapatkan setelah peneliti melakukan penelitian, yaitu berupa wujud unsur pembangun dalam novel Mata di Tanah Melus karya Okky Madasari yang berwujud fakta cerita (alur, tokoh, latar), tema, sarana cerita (judul dan sudut pandang). Dalam novel Mata di Tanah Melus karya Okky Madasari terdapat unsur pembangun yang berfungsi untuk memahami dan memaknai karya sastra secara utuh. Adapun unsur pembangun yang terdapat dalam novel ini berupa fakta cerita (alur, tokoh, latar), tema, sarana cerita (judul dan sudut pandang).

\section{Fakta Cerita}

Fakta cerita sebagai salah satu informasi yang berupa fakta yang terdapat di dalam karya sastra yang meliputi satu informasi yang berupa fakta yang terdapat dalam suatu karya yang meliputi alur, karakter, dan latar. Dalam novel Mata di Tanah Melus karya Okky Madasari terdapat fakta cerita yang berupa alur, tokoh, dan latar.

\section{Alur}

Alur pada cerita fiksi menampilkan peristiwa-peristiwa atau kejadian-kejadian yang disampaikan kepada pembaca. Alur bertujuan membuat pembaca sadar terhadap peristiwa-peristiwa atau rangkaian cerita yang terjadi.

\section{Awal atau Peristiwa}

Di tahap ini mulai ada kejadian-kejadian awal yang menjadikan beberapa konflik. Pada cerita novel Mata di Tanah Melus awal peristiwanya dimulai ketika Matara dan Mamanya pergi ke Belu untuk liburan bersama. 
"Kuinjakan kakiku di landasan bandara kecil itu. Bandara yang begitu sepi, hanya ada pesawat kami" (Okky Madasari, 2018: 31)

Alur peristiwa dalam cerita ini dimulai dengan sampainya Matara dan Mamanya di Belu. Selanjutnya, dimulailah tahap konflik dalam cerita Mata di Tanah Melus karya Okky Madasari.

\section{Tengah atau Konfliks}

Konflik dimulai ketika Matara berpisah dengan Mamanya. Setelah melakukan upacara di Hol Hara Ranu Hitu Matara dan Mamanya berpisah sehingga, mengantarkan Matara tersesat ke Tanah Melus. Hal ini dapat di lihat pada kutipan berikut.

"Dua orang kini berjalan mendekatiku. Aku tak bisa lagi menahan rasa takutku. Aku menangis. Saya mau pulang. Mama...Mama" (Okky Madasari, 2018: 79)

"Ema Naim menaruh tangannya di kepalaku. Aku menahan napas. Jantungku berdetak kencang " (Okky Madasari, 2018: 93)

Pada kutipan di atas menunjukan bahwa konflik dimulai dalam cerita. Matara berpisah dengan Mamanya ketika selesai melakukan upacara di Hol Hara Ranu Hitu. Matara menemui dua orang laki-laki yang tak dikenal olehnya, yaitu orang-orang Melus sehingga Matara menangis ketakutan dan ingin pulang bertemu dengan Mamanya. terlihat bahwa Matara menangis ketakutan karena tersesat dan berpisah dari Mamanya. Matara menagis dan terus menangis karena Ia digiring oleh dua pemuda Melus untuk menemui Ema Naim. Matara bertemu dengan Ema Naim, tokoh adat di Kampung Melus. Ketakutannya pun semakin menjadi-jadi. Namun, karena ia bertemu dengan Atok salah satu penduduk di Tanah Melus membuat ia tidak terlalu khawatir.

\section{Klimaks atau Akhir}

Pada tahap ini, pembaca mulai mendapatkan konflik yang telah dimunculkan pada tahap sebelumnya dan semakin berkembang, Akhir cerita atau klimas dimulai ketika Matara dan Atok keluar dari sungai yang 
penuh dengan Buaya. Mereka menemui titik terang untuk kembali ke Tanah Melus. Sepanjang perjalanan mereka belum menemui jalan keluar menuju Tanah Melus. Semakin maju dan maju Matara dan Atok melihat cahaya merah api unggun dari sudut hutan.

Dalam suasana yang kian gelap, samar-samar terlihat ada cahaya terang" (Okky Madasari, 2018: 165)

Pada kutipan diatas menggambarkan bahwa Matara dan Atok dalam keadaan gelap mereka melihat cahaya terang. Ternyata cahaya tersebut berasal dari Api unggun yang berada di dalam hutan. Mereka berdua semakin mendekati sumber Api tersebut. Lama-kelamaan berjalan, akhirnya mereka sampai ke sumber cahaya dan Matara akhirnya bertemu dengan Mamanya.

Alur cerita pada novel Mata di Tanah Melus adalah alur maju karena peristiwanya diceritakan dari awal sampai akhir secara berurutan. Alur maju diceritakan dari masa lalu ke masa kini secara teratur dan berurutan dari awal kejadian cerita sampai akhir cerita. Hal ini sesuai dengan wawncara yang di lakukan oleh Okky Madasari bersama Tempo Co.

"Pada lima novel sebelumnya, Okky kerap menggunakan alur maju-mundur dalam bercerita. Akibatnya, kadang pembaca dibuat sedikit pusing dan juga penasaran. Ditambah lagi tiap babnya bisa berpuluh-puluh halaman. Saya sempat khawatir hal yang sama terjadi pada novel terbarunya ini. Namun, ternyata segmentasi kepada anak-anak membuat okky membuat jumlah halaman setiap bab menjadi lebih sedikit. Mayoritas alur yang digunakan juga adalah alur maju." (Wawancara Okky Madasari bersama Tempo Co)

Berdasarkan kutipan tersebut dapat disimpulkan bahwa alur yang digunakan dalam novel Mata di Tanah Melus karya Okky Madasari menggunakan alur maju. Pada novel sebelum-belumnya Okky Madasari sering menggunakan alur maju-mundur. Namun, ketika dalam novel yang bergenre sastra anak seperti ini Okky Madasari mampu keluar dari cerita yang beralur campuran dan memilih mengguakan alur maju untuk mengemas cerita anak. Alur maju yang dikemas dalam cerita anak 
bertujuan agar anak sebagai pembacaa tidak bingung, sehingga dapat memahami dan menikmati cerita secara utuh.

\section{Tokoh}

Dalam cerita fiksi sastra anak, tokoh pada sebuah cerita tidak harus berwujud manusia, melainkan dapat berupa binatang atau suatu objek yang lain yang biasanya merupakan bentuk personifikasi dari manusia. Dalam sebuah cerita terdapat tokoh utama, tokoh tambahan, tokoh hitam, dan tokoh putih. Menurut (Suhardi, 2011: 3) mengatakan bahwa tokoh adalah pelaku dalam sebuah cerita.

\section{Tokoh Utama}

Tokoh utama adalah tokoh yang menggambil bagian terbesar dari suatu cerita. Jadi, tokoh utama merupakan tokoh yang menjadi peran terpenting dalam suatu cerita. Tokoh utama dalam cerita keberadaannya berhubungan dengan peristiwa dalam cerita, sehingga menjadi pusat perhatian dan posisinya dominan sebagai tokoh cerita.

"Ini pertama kalinya aku naik pesawat, pertama kalinya pula aku berpergian jauh hanya dengan Mama" (Okky Madasari, 2018: 23)

Matara sebagai tokoh utama memulai pertualangannya dengan menaiki pesawat bersama Mamanya. Pada data tersebut Matara dikatakan sebagai tokoh utama "aku" karena dalam sub-bab ini Matara dan Mamanya dominan mengambil bagian dalam sub-bab empat. Pada kutipan di atas dilukiskan bahwa Matara mengendarai pesawat bersama Mamanya menuju Belu untuk menjalankan liburan.

"Dalam proses penulisan, saya sebagai pengarang melihat segala sesuatu dari kacamata anak-anak, utamanya tokoh utama dalam novel itu yang berumur 12 tahun. Saya meleburkan diri dalam karakter, pikiran, dan jiwa anak-anak, sehingga kemudian rangkaian kisah mengalir begitu saja sehingga bisa dinikmati anak-anak" (Wawancara okky Madasari bersama Tempo Co)

Berdasarkan kutipan tersebut tampak bahwa yang berperan menjadi tokoh utama adalah Matara. Dengan adanya bukti wawancara 
yang dilakukan Tempo Co kepada Okky Madasari memperkuat hasil penelitian yang dilakukan oleh peneliti bahwa tokoh utama dalam novel Mata di Tanah Melus adalah Matara. Tokoh utama Matara berperan sebagai "aku" lebih banyak membawakan kecenderungan mengenai dirinya sendiri dan bersifat dominan terhadap tokoh Matara. Tokoh Matara memiliki perwatakan yang cerdas, tangguh, dan bersahabat. Matara adalah anak yang berusia 12 tahun dan satu-satunya anak dari keluarga Mama dan Papaya.

\section{Tokoh Pembantu}

Tokoh Pembantu merupakan tokoh yang kontras dengan tokoh lainnya dan membantu menjelaskan tokoh lainnya. Tokoh pembantu memerankan bagian yang penting dalam cerita, tetapi hanya sebagai pembantu. Misalnya dalam novel Mata di Tanah Melus seperti tokoh Mama Matara, Papa, Tania, Mama Tania, Atok, Ratu Kupu-Kupu, Raja Buaya, Ibu Atok, Ema Nain, Laka Lorak, Paman Tania, dan Reinar.

\section{Mama Matara}

Dalam novel Mata di Tanah Melus yang berperan sebagai tokoh pembantu adalah Mama Matara. Dimana Tokoh Mama tidak begitu berperan dalam cerita. Namun, Mama Matara tetap berperan dari awal sampai cerita itu selesai walaupun ada bagian cerita yang tidak ada perannya.

"Mama pun tampak puas dan senang. Ia tak pernah lagi datang ke sekolah untuk marah pada guru dan kepala sekolah" (Okky Madasari, 2018:17)

Mama Matara dapat dikatakan sebagai tokoh pembantu karena perannya tidak diutamakan. Namun, tanpa peran dari tokoh Mama Matara, maka cerita dalam novel Mata di Tanah Melus akan terasa hambar. Mama Matara dalam kutipan tersebut tampak senang terhadap kebijakan guru yang ada di sekolah Matara karena Matara tidak diberi PR dan tidak diberi cerita-cerita yang menakutkan tentang penyiksaan di dalam kubur dan neraka. Tidak hanya itu, tidak ada juga guru galak di sekolah.

\section{Papa Matara}


Papa Matara juga termasuk tokoh pembantu dalam cerita novel Mata di Tanah Melus perannya dalam cerita ini tidak terlalu banyak. Namun, peran tokoh Papa Matara dapat kita lihat pada data berikut. Papa Matara mengalungkan kamera di leher Matara dan memotret Matara.

"Papa mengalungkan kamera itu dileherku. Lalu ia memotretku dengan HP-nya" (Okky Madasari, 2018:30)

Berdasarkan kutipan di atas dapat dilihat bahwa Papa Matara mempunyai sifat yang penyayang. Hal ini dapat terlihat kertika Papa Matara mengalungkan kamera di leher Matara sebelum Matara pergi ke Belu. Papa Matara juga memotret dengan Hp wajah Matara sebelum Papanya berpisah dengan Matara. Tokoh Papa Matara hanya berperan di bagian sub-bab Papa.

\section{Reinar}

Reinar adalah salah satu tokoh pembatu dalam novel Mata di Tanah Melus. Reinar merupakan sopir dari Matara dan Mama yang mengantarnya dari Bandara menuju Hotel. Tokoh Reinar hanya berperan pada bagian ketika Reinar mengantarkan Matara ke Hotel saja.

"Reinar nama laki-laki itu. Ia mengulurkan menyodorkan tangannya padaku sambil membungkam punggungnya agar tingginya menyamaiku" (Okky Madasari, 2018: 31-32)

Pada kutipan di atas tampak bahwa Reinar mengulurkan tangannya kepada Matara sebagai tanda perkenalannya kepada Matara. Reinar dikatakan sebagai tokoh tambahan karena perannya hadir dalam bentuk dialog bersama Matara dan peran Reinar dalam cerita novel Mata di Tanah Melus hanya berperan pada sub-bab Sapi-Sapi Belu saja.

\section{Ketua RT}

Tokoh pembantu lainnya yang ada dalam novel Mata di Tanah Melus yaitu Ketua RT. Tokoh Ketua RT muncul ketika Mobil Reinar menabrak sapi. Dimana ketua RT berperan sebagai tokoh adat yang menjadi penengah atas kematian sapi yang ditabrak oleh Reinar. 
"Ketua RT itu berdiri lalu meninggalkan kami, sepertinya sengaja memberikan kesempatan agar Mama dan Reinar bisa bicara berdua" (Okky Madasari, 2018: 37)

\section{Tania}

Tania adalah tokoh pembantu yang setia menjadi tokoh pembantu sampai cerita selesai. Tania merupakan teman yang pertama kali Matara temui di Belu. Tania merupakan gadis kecil yang sama umurnya dengan Matara. Selama di Belu Matara bermain dengan Tania. Tokoh Tania mulai berperan pada sub-bab Berjalan Bersama Tania. Hal ini dapat dilihat pada data berikut.

“Kita balik saja ke psar yuk, tan."(Okky Madasari, 2018: 49)

"Tania menuruti permintaanku meski dengan wajah bersengut-sengut" (Okky Madasari, 2018: 49)

\section{Ibu Tania}

Ibu Tania juga merupakan tokoh pembantu yang ada dalam novel Mata di Tanah Melus. Ibu Tania adalah seorang pedagang pasar yang ada di Belu. Ia memiliki anak yang bernama Tania, yang merupakan teman dekat dari Matara pada saat Matara berada di Belu.

"Ibu Tania berdiri di samping tempat tidurku" (Okky Madasari, 2018: 50)

Berdasarkan data 41 tampak bahwa Ibu Tania berdiri disamping tempat tidur Matara. Pada saat itu, Matara jatuh pingsan dan ditolong oleh Tania dan Ibu Tania. Peran Ibu Tania dalam cerita novel Mata di Tanah Melus berperan sampai akhir cerita walaupun perannya hanya sebagai tokoh pembantu. Hal ini dapat dilihat pada data berikut.

\section{Paman Tania}

Peran Paman Tania dalam novel Mata di tanah Melus menjadi tokoh pembantu dibuktikan dengan adanya data di bawah. Dimana Paman Tania membacakan mantra pada daun sirih yang akan diletakan di kepala Matara. Peran Paman Tania dalam novel ini juga berlanjut sampai cerita berakhir. 
"Paman Tania mengeluarkan beberapa lembar daun sirih pada kantongnya. Sambil memegang uang dan daun sirih ia komat-kamit, beberapa kali suaranya terdengar tapi aku tak tahu yang dikatakan karena dalam bahasa daerah" (Okky Madasari, 2018: 60)

\section{Kakek}

Kakek berperan sebagai tokoh pembantu dalam novel Mata di Tanah Melus karya Okky Madasari. Tokoh kakek berperan sebagai orang yang bertindak sebagai pemimpin dalam melakukan upacara keselamatan Matara dan Mamanya. Peran kakek dalam cerita ini hanya sebentar, yaitu hanya berperan ketika Matara dan Mamanya meminta perlindungan agar dijauhkan dari segala maran bahaya.

"Kakek itu memimpin kami semua memasuki bangunan yang berupa batu-batu yang tertata rapi setinggi kepalaku" (Okky Madasari, 2018: 66)

\section{Ema Naim}

Tokoh pembantu lainnya yang juga berperan dalam cerita novel Mata di Tanah Melus karya Okky Madasari adalah Ema Naim. Ia adalah Tokoh Adat di Tanah Melus. Hal ini dapat dilhat dalam kutipan di bawah yang menjelaskan bahwa Ema Naim yang mengusap kepala Matara untuk membacakan mantra supaya menjadi orang melus dan diterima oleh bangsa melus.

"Ema Naim menaruh tangannya di atas kepalaku. Aku menahan napas. Jantungku berdetak kencang" (Okky Madasari, 2018: 93)

\section{Mama Atok}

Mama Atok adalah tokoh pembantu yang berperan untuk mendampingi Matara ketika berada di Tanah Melus. Mama Atok setia untuk menjaga Matara ketika berada di sana. Mama Atok meiliki sifat yang baik. 
"Mama Atok memandangku lekat-lekat. Ia tak menaggapi permintaanku hingga aku terpaksa mengulangnya" (Okky Madasari, 2018: 84)

Atok

Atok ialah tokoh pembantu yang sangat berpengaruh dalam kehidupan Matara. Tokoh Atok selalu mendampingi Matara selama Matara berada di Tanah Melus. Dimana Atok membawa Matara untuk berkeliling Kampung dan menunjukan satu semi satu rumah-rumah yang berada di sana. Tokoh Atok Ini sangat berperan dalam cerita karea di Tanah Meluslah Atok dan Matara bertemu, sehingga sampai akhir cerita Atoklah yang menunjukan jalan bagi Matara dan Mamanya keluar dari tanah Melus.

"Atok menyalipku dan berlari paling depan. Ia mencarikan jalan untuk kami. Kami terus mengikutinya. Aku tersengalsengal kehabisan napas, tapi aku tak boleh berhenti. Kami semua tak boleh berhenti" (Okky Madasari, 2018: 184)

Pada kutipan di atas dapat dilihat bahwa tokoh Atok memiliki sifat yang baik. Ia rela mencarikan jalan keluar untuk Matara, Mamanya, dan Para Ilmuan untuk keluar dari Tanah Melus dengan berlari sekuat tenaga hingga Atok menemui padang rumput yang berada di luar Tanah Melus. Pengejawatan nilai baik yang dimiliki oleh Atok dapat dijadikan sebagai nilai yang dapat diperoleh pembaca.

\section{Maun Iso}

Maun Iso adalah tokoh pembantu yang berperan sebagai tokoh adat yang ada di Tanah melus. Ia adalah teman dari Ema Naim yang juga berperan sebagai tokoh adat disana. Maun Iso dapat dikatakan sebagai tokoh pembantu karena karkaternya tidak selalu dimunculkan dalam cerita. Perannya hanya sebagian saja dalam cerita.

"Maun Iso mulai bicara dengan suara yang besar. Laki-laki masih muda itu terlihat begitu berwibawa dan dipatuhi semua orang" (Okky Madasari, 2018: 111)

\section{Ratu Кири-Кири}


Ratu Kupu-Kupu ialah tokoh pembantu yang merupakan tokoh setengah hewan dan manusia. Dalam cerita ini Ratu Kupu-Kupu berpran sebagai tokoh binatang yang merupakan tokoh pengejawatan dari norma-norma yang ada. Hal ini tampak pada data berikut.

"Ratu kupu-kupu berjalan mendekati kami. Sayapnya terkepak pelan-pelan" (Okky Madasari, 2018: 125-126)

\section{Dewa Buaya atau Bei Nai}

Dewa Buaya adalah tokoh pembantu yang perannya hanya mengambil sedikit bagian dalam cerita. Dewa buaya dalam novel Mata di Tanah Melus dikenal dengan sebutan Bei Nai yang memiliki peran sebagai pelindung Tanah Melus.

"Bei Nai, Dewa Buaya. Pelindung Melus. Pemberi kekuatan para Maun" (Okky Madasari, 2018: 154)

\section{Para Pemburu}

Para Pemburu adalah orang-orang yang ingin menguasai Lakaan. Mereka memburu semua yang ada di Tanah Melus seperti memburu Buaya-Buaya. Para pemburu merupakan tokoh pembantu dalam novel Mata di Tanah Melus.

"Ada delapan laki-laki dewasa. Semuanya memanggul tas, beberapa membawa senapan. beberapa orang Belu dan beberapa lainnya seperti orang yang tinggal di Jakarta" (Okky Madasari, 2018: 157)

"Kami tiba di sungai seluruh pemburu kini mengangkat senapannyal" (Okky Madasari, 2018: 161)

Kutipan di atas menunjukan bahwa ada delapan orang laki-laki dewasa yang memanggul tas dan membawa senapan. Kedelapan laki-laki dewasa tersebuta adalah para pemburu yang ingin memburu buayabuaya yang ada di sungai Melus. Dikatakan sebagai tokoh pemburu karena pada data tersebut ia membawa senapan yang digunakan untuk memburu buaya.

\section{Para Ilmuan}


Para Ilmuan berperan sebagai tokoh pembantu dalam cerita novel Mata di Tanah Melus. Tokoh Para Ilmuan berperan di bagian akhir cerita yang mengantarkan Mama Matara bertemu dengan Matara.

“Gila, luar biasa!seru salah satu ilmuan. (Okky Madasari, 2018: 171)

"Para Ilmuan melanjutkan kesibukannya" (Okky Madasari, 2018: 175)

Dalam kutipan di atas diktehui Para Ilmuan melihat suatu kejadian yang tak terduga, yaitu adanya pulau di tengah-tengah lautan di musim panas yang di sebut Lakaan. Para ilmuan ini adalah teman-teman dari Mama Matara yang ikut untuk mencari Matara di Tanah Melus.

\section{Laka Lorak}

Laka Lorak ialah tokoh pembantu dalam cerita. Ia merupakan sosok perempuan yang melindungi Atok, Matara, Mama Matara, dan Para Ilmuan ketika teromabang-ambing di Air. Dikatakan sebagai tokoh pembantu karena peran Laka Lorak hanya berperan sedikit tidak menguasai cerita.

"Di tengah badai, muncul sosok perempuan. Perempuan itu melayang, meliuk-liuk di antara tiupan angin. Perempuan itu serupa cahaya, serupa udara, Laka Lorak seru Atok" (Okky Madasari, 2018: 176)

\section{Manusia - Manusia Melus}

Tokoh Pembantu dalam novel Mata di Tanah Melus, yaitu ManusiaManusia Melus. Pada data 55 tampak bahwa Manusia-Manusia Melus yang berperan dalam cerita ini berjumlah enam laki-laki dewasa. Matara bertemu degan tokoh ini ketikka Matara tersesat di Tanah Melus.

"Ada enam orang dihadapanku. Enam laki-laki dewasa, tiga orang di depanku, tiga orang di depanku. Semua berambut panjang, berkulit legam, berbadan kekar, dan tidak bersendal" (Okky Madasari, 2018: 78) 


\section{Tokoh Putih}

Tokoh putih ialah tokoh yang dapat dikategorikan sebagai tokoh yang berkarakter baik dan mengejawatkan nilai-nilai kebenaran. Dalam novel Mata di Tanah Melus tokoh yang merupakan tokoh putih, yaitu Matara, Mama Atok, Atok, Ratu Kupu-Kupu, dan Tania dan Mamanya.

\section{Matara}

Matara merupakan tokoh putih dalam cerita. Matara mempunyai sifat penyabar, bekerja sama dan pantang menyerah. Sabar menurut Umar Yusuf (2010), dapat diartikan sebagai kemampuan mengatur, mengendalikan, mengarahkan, (pikiran, perasaan, dan tindakan), serta mengatasi kesulitan secara komprehensif dan intrerogatif.

Sifat pantang menyerah ditunjukan ketika Matara ingin keluar dari Kerajaan Kupu-Kupu. Walaupun Ia harus melewati sungai yang ada buayanya, menyusuri pohon kaktus yang penuh duri, dan bertemu dengan para pemburu. Namun, tekadnya sangat kuat untuk bertemu dengan orang tuanya.

"Kita bisa melakukannya, Tok. Kita bisa berenang" (Okky Madasaru Madasari, 2018:149)

Berdasarkan kutipan di atas Matara mempunyai sifat mampu bekerja sama dengan orang lain. Hal ini dapat kita lihat ketika Matara bekerja sama dengan Atok untuk bersama-sama berenang agar sampai ke daratan. Ia selalu memberikan keyakinan kepada Atok bahwa mereka dapat melewatinya.

\section{Atok}

Selain Matara, tokoh putih dalam cerita ialah Atok. Atok adalah tokoh yang mempunyai sifat kerja keras, pantang menyerah, berjiwa penolong, baik hati dan bersahabat. Sifat baik hati ditunjukan pada kutipan di bawah ini. Dimana Atok memberikan sebutir kelapa untuk diminum oleh Matara.

"Pintu pelan-pelan terbuka. Atok masuk. Ia menyodorkan sebutir kelapa, ini minumlah." (Okky Madasari, 2018: 115) 
Inisiatif adalah konsep kedua dari keberanian. Inisiatif merupakan hal ketika orang yang menunjukkan keberanian dengan memulai tindakan (Garmo, 2013:113). Seorang anak pemberani memiliki inisiatif dengan memulai tindakan tanpa perintah dari siapapun. Pada kutipan di atas Atok tampak mempunyai inisiatif dan bersifat baik untuk membuka pintu pelan-pelan dan masuk untuk memberikan sebutir kelapan untuk Matara. Situasi dalam hal ini Atok di larang oleh orang-orang Melus untuk memberikan apa-apa kepada Matara. Namun, Atok tetap memberikan minuman kelapa muda agar Matara bisa minum. Dari data di atas dapat dikatakan Atok merupakan tokoh putih yang mempunyai sifat tolongmenolong. Sifat tolong-menolong dapat dicerminkan ketika Atok memberikan minum kepada Matara. Dengan adanya sifat tersebut pembaca juga dapat mengambil nilai moral dari tokoh Atok. Dalam kehidupan sehari-hari penting untuk menerapkan sifat saling tolongmenolong antar sesama.

\section{Mama Atok}

Mama Atok juga dapat dikatakan sebagai tokoh putih. Hal ini dikarenakan Mama Atok yang sering membantu dan melindungi Matara. Mama Atok memiliki sifat penyayang. Pada data di bawah ini tampak sifat penyayang dari Mama Atok, yaitu ketika Mama Atok menghapus air mata Matara dan berusaha menghibur Matara.

Mama Atok mengusap-usap punggung dan pundaku. Menghapus air mata yang mengalir dipipiku. Lalu ia menarik tanganku agar aku berdiri. Ia menuntunku dan berkata, mainlah sana. Itu Atok sedang main sama temanteman yang lain" (Okky Madasari, 2018: 114)

Dari kutipan di atas dapat dilihat bahwa Mama Atok mempunyai sifat yang baik. ia mempunyai jiwa penyayang dengan mengusap-usap punggung, pundak, dan mengusap air mata Matara. Ia juga menyuruh Matara untuk bermain dengan Atok Tokoh Mama Atok yang mempunyai jiwa penyayang dapat di contoh oleh anak-anak untuk saling menyayangi antar sesama manusia.

\section{Ratu Кири-Кири}


Ratu kupu-kupu merupakan tokoh putih dalam cerita. Hal ini dibuktikan dengan sifat-sifat yang ditunjukan oleh Ratu Kupu-Kupu. Ratu Kupu-Kupu memiliki sifat yang baik. Hal ini dapat dilihat ketika Ia menyajikan makanan untuk Atok dan Matara. Berikut data yang mengungkapkan karakter dari Ratu Kupu-Kupu.

"Ratu Kuрu-Kирu menyajikan makanan di atas meja. Ada satu mangkuk besar berisi madu. Ada piring panjang berisi helai mahkota bunga, ada mangkuk yang terlalu besar berisi benang sari, ada piring bulat besar berisi bunga matahari. Ada buah-buah kecil, lebih kecil dari ceri. Ada rumput berwarna kekuningan. Lalu ada minuman berwarna merah yang katanya terbuat dari daging pohon kaktus. (Okky Madasari, 2018: 128)

Berdasarkan kutipan di atas dapat dilihat bahwa Ratu Kupu-Kupu dapat dikatakan sebagai tokoh putih karena dilihat dari sikap pada data tersebut, yaitu Ratu Kupu-Kupu menyajikan makanan dan memberikan minuman kepada Atok dan Matara. Sikap pemberi yang dilakukan oleh Ratu Kupu-Kupu dapat dipetik oleh pembaca agar diterapkan dilingkugan Masyarakat khususnya anak-anak. Dengan anak membaca novel ini anak dapat memetik nilai saling memberi atas sesama.

\section{Tania dan Mamanya}

"Mataaaa! Mama Mata!

Kini aku bisa melihat siapa yang memanggil kami. Tania dan Keluarganya. Mama Tania memeluku, lalu ganti memeluk Mama" (Okky Madasari, 2018: 117)

Dengan adanya data 60 dapat diketahui bahwa Tania dan Mamanya mempunyai watak yang baik. Tania dan Mamanya rela berharihari mencari Matara dan Mamanya yang tersesat di Tanah Melus. Melihat sikap dan tingkah laku dari Tania dan Mamanya yang mempunyai jiwa penolong dan bertanggung jawab. Dapat dikatakan bahwa Tania dan Mamanya memiliki sifat yang baik dan dapat ditiru oleh pembaca dalam kehidupan sehari-hari.

\section{Tokoh Hitam}


Tokoh hitam dalam cerita anak merupakan tokoh yang berkebalikan dengan tokoh putih dan bersifat jahat. Pada penelitian Desi Noviasari (2019) tokoh hitam merupakan tokoh yang meliputi serakah, keras kepala, egois, kejam, dan tidak adil. Dalam novel Mata di Tanah Melus tokoh yang berperan sebagai tokoh hitam adalah Para Pemburu. Para pemburu dapat dikatakan sebagai tokoh yang kejam karena merusak dan tega terhadap binatang. Hal ini tampak pada kutipan berikut.

"Kami tiba di pinggir sungai. Seluruh pemburu kini mengangkat senapannya. Dalam hati aku berharap tak ada buaya yang menampakan diri" (Okky Madasari, 2018: 161)

“Tapi ...Dorrr!” (Okky Madasari, 2018: 161)

"Salah satu senapan sudah meletus. Semua orang berjalan kerah peluru ditembakan. Seekor buaya tertembak. Mereka bersorak sambil megacung-acungkan senapan" (Okky Madasari, 2018: 161)

Tokoh hitam dalam cerita novel Mata di Tanah Melus ialah para pemburu. Dapat dikatakan sebagai tokoh hitam karena Para Pemburu mempunyai sifat perusak. Ia tega membunuh para buaya-buaya untuk diambil daging dan kulitnya. Tokoh seperti ini tidak diperkenankan ditiru oleh pembaca. Hal ini dapat dilihat pada kutipan di atas bahwa para pemburu mengangkat senapannya dan menembak salah satu buaya. Jadi, sikap dari tokoh pemburu tidak untuk ditiru oleh pembaca karena hal seperti itu, adalah sifat pengrusak yang tega untuk memusnahkan makhluk hidup. Sebagai manusia semestinya kita harus saling melestarikan dan menyayangi makhluk hidup, bukannya memusnakan hewan yang dilidungi.

\section{Latar}

Latar cerita adalah tempat, waktu, sejarah dan interaksi sosial dalam sebuah cerita yang meliputi letak geografis waktu terjadinya dan lingkungan religius. Dalam cerita fiksi anak latar lebih dirasakan kehadirannya. Oleh karena itu, latar diceritakan lebih jelas dan rinci. Dalam cerita fiksi anak terdapat tiga jenis latar cerita, yaitu latar tempat, latar waktu, dan latar sosial-budaya. Hal ini sesuai dengan pendapat dari 
Nurgiyantoro (2005: 227) mengatakan bahwa unsur latar dibedakan atas tiga unsur, yaitu latar tempat, latar waktu, dan latar sosial-budaya.

\section{Latar Tempat}

Latar tempat adalah adalah latar yang berkaitan dengan masalah geografis menyangkut deskripsi tempat suatu peristiwa cerita terjadi. Jadi, latar tempat merupakan tempat terjadinya peristiwa. Adapun latar tempat dalam novel Mata di Tanah Melus terletak di Belu, Kamar Hotel, Rumah Tania, Fulan Fehan, Kampung Melus, Sekolah, Rumah Atok, Dalam Pesawat, Landasan Bandara, Lapak Pedagang Buah, Pinggir Jalan, Hol Hara Ranu Hitu, Gubuk, Lapangan, Kerajaan Kupu-Kupu, dan sungai.

\section{Belu}

Tempat terjadinya peristiwa dalam novel Mata di Tanah Melus terjadi di Belu. Dimana Matara dan Mamanya melewatkan malan pertama. Di Belu mereka tidak makan malam karena uang mereka habis untuk membayar denda 20 Juta.

"Kami melewatkan malam pertama di Belu tanpa makan malam" (Okky Madasari, 2018:39)

Dari data diatas dapat diketahui bahwa Belu merupakan latar yang ada pada novel Mata di Tanah Melus.

\section{Latar Waktu}

Latar waktu adalah hal yang mengacu pada saat terjadinya peristiwa dalam alur secara historis. Latar waktu mengacu pada waktu kejadian suatu peristiwa. Misalnya dalam novel Mata di Tanah Melus, yaitu latar waktunya terjadi pada malam, siang, dan pagi hari. Hal ini tampak pada kutipan berikut.

"Pada malam sebelum keberangkatan kami pula, papa datang

kekamarku. Dia memeluku dan memberi hadiah sebuah kamera

baru, kamera kecil yang canggih" (Okky Madasari, 2018:29)

Latar waktu yang ada dalam novel Mata di Tanah Melus terjadi pada malam hari. Hal ini tampak pada kutipan di atas, yaitu terjadi pada malam hari. Dimana pada saat itu Papa dari Matara memberikan kamera di dalam kamar pada malam hari. 
"Jam dua belas siang. Kami berdua kembali menyusuri jalanan menuju rumah Tania." (Okky Madasari, 2018:47)

Berdasarkan kutipan di atas tampak bahwa latar waktu dalam novel Mata di Tanah Melus terjadi pada siang hari. Dimana pada kutipan diatas digambarkan bahwa Matara dan Mamanya pergi menyusuri jalan tepat jam dua belas siang.

"Kami meninggalkan hotel jam sembilan pagi seusai sarapan" (Okky Madasari, 2018:40)

Latar waktu pada cerita novel Mata di Tanah Melus terjadi pada pagi hari. Hal ini dapat dilihat pada kutipan di atas bahwa pada pagi hari Matara dan Mamanya meninggalkan Hotel seusai mereka sarapan. Pada pagi hari itulah mereka pergi menuju pasar untuk memotret kehidupan Masyarakat yang ada di Belu.

\section{Latar Sosial-Budaya}

Latar sosial mengarah pada hal-hal yang berhubungan dengan perilaku kehidupan sosial masyarakat. Pada suatu daerah yang diceritakan dalam karya fiksi. Latar sosial pada novel Mata di Tanah Melus karya Okky Madasari adalah masyarakat Belu, Tanah Melus Nusa Tenggara Timur Indonesia. Hal ini tampak pada kutipan berikut.

"Bunyi gendang kian mengeras. Kini malahan mengalunkan musik riang penuh semangat. Orang-orang berdiri, menari-

nari mengikuti tabuhan gendang. (Okky Madasari, 2018: 94)

Berdasarkan kutipan di atas kehidupan sosial orang-orang di Tanah Melus hidup rukun. Apabila ada orang yang datang di Kampung Melus, maka akan diadakan upacara pembersihan dengan diadakannya tarian-tarian yang diringi tabuhan gendang.

\section{Tema}

Tema merupakan gagasan sentral, yakni sesuatu yang hendak diperjuangkan melalui karya fiksi dan sejenis komentar terhadap subjek baik secara eksplisit maupun implisit.

Dalam novel Mata di Tanah Melus karya Okky Madasari adapun tema yang disajikan pengarang sangat menarik sehingga membuat 
pembaca novel khususnya anak-anak menjadi merasakan ikut terlibat langsung masuk dalam cerita menikmati isi cerita yang disajikan. Sesuai dengan judul novel Mata di Tanah Melus novel ini memberikan kisah petualangan gadis kecil bernama Matara di Tanah Melus. Oleh karena itu, tema dari novel ini adalah kemanusiaan. Hal ini tampak pada data berikut.

"Saat berlari jauh melewati para pemburu itu, Mata berkata pada Atok, "Mereka mau menangkap buaya Tok," kataku sambil berjalan. "Sudah dari dulu," kata Atok. "Itulah sebabnya semakin jarang kita lihat buaya. Semua dibunuh, diambil mereka." "Apakah buaya-buaya yang tadi kita lihat akan mati semua, Tok? (Madasari, 2018: 161)

Berdasarkan kutipan di atas Matara dan Atok berlari kembali kearah sungai untuk menyelamatkan para bauaya. Mereka berpura-pura untuk bergabung bersama para pemburu dengan tujuan mnyelamatkan dewa buaya dan para buaya lainnya. Pada saat salah satu buaya tertembak Atok berteriak Bei Nai! Untuk memanggil Dewa Buaya, seketika para buaya muncul dan melilit Para Pemburu.

"Apakah tema-tema sosial khas Okky tetap melekat dalam karya tersebut?

"Harapan saya, jika saat anak-anak mereka telah membaca karya semacam ini, mereka akan tumbuh menjadi manusia yang berpikiran terbuka dan menjunjung tinggi nilai-nilai kemanusian," tutur Okky. Jawaban tersebut menyiratkan melalui sastra anak, Okky tak melepas kesetiaannya terhadap tema kemanusiaan yang selama ini ia usung." (Wawancara Tempo Co bersama Okky Madasari)

Tema dalam novel Mata di Tanah Melus karya Okky Madasari disajikan pengarang sangat menarik sehingga membuat pembaca novel khususnya anak-anak menjadi merasakan ikut terlibat langsung masuk dalam cerita menikmati isi cerita yang disajikan. Tema yang diangkat dalam data yang diteliti, yaitu bertemakan kemanusiaan. Matara sebagai tokoh utama digambarkan sebagai seorang pemberani yang diam-diam memiliki jiwa humanis.

\section{Sarana Cerita}


Sarana cerita sebagai metode memilih dan menyusun detail cerita, sarana-sarana cerita harus digunakan secara masuk akal agar pembaca menjadi terkendali. Sarana-Sarana dalam cerita dapat diartikan sebagai metode pengarang yang digunakan untuk memilih cerita agar tercapainya pola-pola yang bermakna. Sarana cerita yang terdapat dalam novel Mata di Tanah Melus karya Okky Madasari berupa judul dan sudut pandang.

\section{Judul}

Judul merupakan elemen fiksi yang pertama dibaca oleh pembaca. Oleh karena itu, judul mudah dikenali oleh pembaca. Biasanya judul dari cerita adalah cerminan dari isi cerita secara keseluruhan. Judul novel Mata di Tanah Melus dapat dipahami dari dua sudut pandang yang berbeda. Hal pertama yang menarik dan membuat penasaran dari judul novel ini adalah pemilihan judul oleh pengarang.

Judul "Mata di Tanah Melus" mengandung dua arti, yaitu pertama berarti mengenai mata yang berpetualang di Tanah Melus dan yang kedua berarti menggambarkan keindahan Tanah Melus. Hal ini menunjukan bahwa judul Mata di Tanah Melus memiliki arti yang kompleks, dan saat membaca pertama kali, sudah menyiratkan isi cerita yang multiprestasi karena Mata di Tanah Melus sebagai frasa yang membentuk penyimpangan interpretasi.

\section{Sudut Pandang}

Sudut pandang dapat dikatakan sebagai sarana cerita dalam novel. Sudut pandang dalam novel, yaitu mengungkapkan posisi pengarang menceritakan sebuah peristiwa pada suatu cerita. Sudut pandang yang digunakan pada novel Mata di Tanah Melus karya Okky Madasari adalah teknik bercerita orang pertama dengan aku sebagai tokoh utama (first-person-central), yaitu tokoh utama aku mengisahkan cerita atau pengalaman hidup dengan kata-katanya.

"Aku punya ibu yang suka menulis cerita" (Okky Madasari, 2018: 13)

Berdasarkan kutipan di atas dapat dikatakan bahwa sudut pandang yang digunakan dalam novel Mata di Tanah Melus karya Okky Madasari menggunkan sudut pandang orang pertama pelaku utama 
karena kata-kata pada kutipan di atas mengunkan kata aku. Dengan sudut pandang yang seperti ini tokoh utama aku yaitu Matara mengisahkan pengalaman hidup dengan kata-katanya.

\section{Kesimpulan}

Unsur Pembangun dalam novel Mata di Tanah Melus, yaitu Fakta Cerita (alur, tokoh, dan latar), Tema, dan Sarana Cerita (judul dan sudut pandang). Berdasarkan hasil penelitian penelitian menunjukan bahwa unsur pembangun yang ditemukan pada novel Mata di Tanah Melus, yaitu fakta cerita berupa alur maju. Tokoh utama adalah Matara, tokoh pembantu terdiri dari 18 orang, tokoh putih berjumlah 5 orang, dan tokoh hitam ialah Para Pemburu. Latar tempat terdiri dari 17 tempat. Latar waktu terjadi pada pagi, siang, dan malam. Latar sosial-budaya mengangkat budaya Suku Melus. Tema yang diangkat dalam novel Mata di Tanah Melus berupa tema kemanusiaan. Sarana cerita berupa judul dan sudut pandang. Judul novel yang mengandung dua arti dan mengalami penyimpangan semantis. Sudut pandang yang digunakan adalah sudut pandang orang pertama pelaku utama. Pada penelitian novel Mata di Tanah Melus karya Okky Madasari, penelitiannya hanya terbatas, yaitu hanya meneliti unsur pembangun dengan menggunakan kajian strukturalisme, sehingga untuk penelitian selanjutnya dapat menggunakan kajian lainnya.

\section{Bibliografi}

A Teeuw. 1984. Sastra dan Ilmu Sastra Pengantar Teori Sastra. Jakarta: PT Dunia Pustaka Jaya.

Aisha Shaidra,"Okky Madasari dan Kisah Buku Terbaru Mata di Tanah Melus," Tempo. Co, 3 Febuari 2018.

Burhan Nurgiantoro. 2016. Sastra Anak: Pengantar Pemahaman Dunia Anak. Yogyakarta: Gadjah Mada University Press.

Chintya Nurikma Irma. 2018. "Nilai-Nilai Pendidikan Karakter dalam Novel Ibuk Karya Iwan Setyawan," Jurnal Retorika, (Online), Vol. 11, No. 1, (https://ojs.unm.ac.id/retorika/article/view/4888

Endaswara, Suwardi. Metedologi Penelitian Sastrra Epistemologi, Model,

Teori, dan Aplikasi. Yogyakarta: CPAS (Center for Academic Publishing Service), 2013.

Faruk. Metode Penelitian Sastra Sebuah Perjalanan Awal. Yogyakarta: Pustaka Pelajar, 2017. 
Fimela, "Review Novel Mata di Tanah Melus-Okky Madasari", Majalah Online Fimela com, 4 Maret 2018. (https://www.fimela.com/fashionstyle/read/3778571/review-novel-mata-di-tanah-melus-okkymadasari)

Heru Kurniawan, dkk., 2018. "Penalaran Moral Anak dalam Cerita pada Majalah Bobo dan Harian Kompas," Poetika Jurnal Ilmu Sastra, (Online), Vol. $\quad 6 \quad$ No. (https://jurnal.ugm.ac.id/poetika/article/view/39017)

Heru Kurniawan. 2013. Sastra Anak Dalam Kajian Strukturalisme, Sosiologi, Semiotika, hingga Penulisan Kreatif. Yogyakarta: Graha Ilmu.

Meylinda, Ulfa dan Eliya, Ixsir. "Peran Startup Digital "Ruangguru" Sebagai Metode Long Distance Learning dalam Pembelajaran Bahasa," Jurnal Edulingua, Vol. 4, No. 2 (2019).

Okky Madasari. Mata di Tanah Melus. Jakarta: PT Gramedia Pustaka Utama, 2018.

Pandu Dian Samaran, dkk. "Analisis Struktural Novel O Karya Eka Kurniawan," Jurnal Ilmiah Korpus, Vol. 2, No. 3 (2018).

Pujiharto. 2012. Pengantar Teori Fiksi. Yogyakarta: Penerbit Ombak.

Sudaryanto. Metode dan Aneka Teknik Analisis Bahasa. Yogyakarta: Sanata Dharma University Press, 2015.

Sugihastuti dan Abi Al Irsyad, Rossi. Teori Fiksi Robert Stanton. Yogyakarta: Pustaka Pelajar Offset, 2007.

Sugiono. Metode Penelitian Kuantitatif, Kualitatif, dan R\&D. Bandung: Alfabeta CV, 2017.

Suminto A, Sayuti. Berkenalan dengan Prosa Fiksi. Yogyakarta: Gama Media, 2000.

Toha Sarumpaet dan Riris K. 2017. Pedoman Penelitian Satra Anak. Jakarta: Yayasan Pustaka Obor Indonesia.

Teeuw, A. Sastra dan Ilmu Sastra Pengantar Teori Sastra. Jakarta: PT Dunia Pustaka Jaya, 1984.

Wellek, Renne dan Warren, Austin. Teori Kesusastraan. Jakarta: PT Gramedia Pustaka Utama, 2016. 